\title{
HUMAN TRAFFICKING IN MALAYSIA: THE RESPONSE OF THE MALAYSIAN GOVERNMENT
}

\author{
Sheila Devi Michael
}

\begin{abstract}
Human trafficking is not only an illicit clandestine movement but a grave transnational organized crime against humanity which has been remarkably on the rise for the past decades. With increasing global and security concern, human trafficking activity has provoked actors and non-actors at international as well as at state levels to play vital roles in combating this crime. Malaysia is identified as a country of origin besides being a lucrative destination and serves as a transit point for traffickers to transport their victims across borders. Concurrently, internal human trafficking has also been reported to occur in Malaysia. Human trafficking imposes numerous security challenges to a state and its people and subsequently on its political, economic and social development. Hence, the Malaysian government in collaboration with its MAPO (Council for Anti-Trafficking in Persons) secretariat has responded by outlining the National Action Plan against Trafficking in Persons (2010-2015) as a preventive measure. This paper will highlight the trends of the crime and discuss the efforts accomplished by the Malaysian government by operating the 3 P framework; namely prosecution, prevention and protection including partnership initiated by the United Nations Protocol. Though the U.S State of Department and some civil societies opined that Malaysia is doing significantly less nevertheless the government has been robust in tackling this modern-day slavery.
\end{abstract}

Keywords: Malaysia, human trafficking, international response, state's response, measures, 3P framework

\section{INTRODUCTION}

Transnational organized crimes have been rampant and on the rise for the past few decades due to multi-facet factors such as abject 
poverty, warfare, ethnic conflicts, unemployment, socio-economic disorder, globalization, migration and climate change. Cross border criminal activities like human trafficking, arm smuggling, drug trafficking, people smuggling, illegal trade in cigarettes, illicit trade of environmental products, smuggling of art and antiques, smuggling of automobiles, pirating and cybercrime ${ }^{1}$ robustly impact the politic and socio-economy of any country in the world. These unlawful clandestine activities operate across the globe on local, national and international platforms among the learned, experienced and professional perpetrators.

The International Labour Organization (ILO) estimates that a minimum figure of persons trafficked into forced labour and sexual exploitation in Asia and the Pacific alone is 1.4 million from the 2.4 million estimated victims globally. ${ }^{2}$ According to numerous international reports, around 2.4 million people are trapped in myriad forms of human trafficking namely, forced and hard labour; various sexual works like forced prostitution and pornographic; child labour and as child soldiers while millions of victims are remained hidden and unidentified as it is operated sophisticatedly with strong chain of networks existing in developed as well as in developing and least developing countries.

The crime of human trafficking has been acknowledged globally by international organizations (IO) as a crime against humanity. And at any given time it is estimated that there are 27 million men, women, and children are trapped as victims of human trafficking around the world. This estimation does not add up to the figure of 40, 000 identified victims as reports provided by the United States on Trafficking in Persons for the year of 2012. ${ }^{3}$ It is a huge challenge for governments and researchers to produce substantial data on human trafficking due to the nature of crime in identifying the many facets it has and the confusion over migrant smuggling, refugees and asylum seekers.

Human trafficking is a heinous global crime and one of the most egregious violations of human rights that the United Nations confronts since $2000 .{ }^{4}$ The definition of human trafficking under the relevant Protocol to the United Nations Convention against Transnational Organized Crime as the "recruitment, transportation, transfer, harbouring, or receipt of persons, by means of the threat or use of 
force or other forms of coercion, of abduction, of fraud, of deception, of the abuse of power or of a position of vulnerability or of the giving or receiving of payments or benefits to achieve the consent of a person having control over another person, for the purpose of exploitation." 5

Human trafficking is also widely known as the modern-day slavery where the people are forced to stay and act against their will, believes, culture and upbringing. ${ }^{6}$ Victims are not only subjected to violence but subjugated and stripped of their freedom. Contemporary slavery is a "social and economic relationship in which persons is controlled through violence or paid nothing and economically exploited." 7

Although this crime has become a lucrative business with multi-billion dollar tagline yet many governments are denying the occurrence of this crime in their respective states which is reaping off the dignity of men, women and children of all ages. Based on its estimated annual earnings amounting to more than US\$40 billion, the crime of human trafficking is the third largest business after drugs and arms trafficking ${ }^{8}$ and it risks the society at large, the economics of the state, the global health and the sovereignty of a state as the nature of the crime undermines the rules and regulations of states.

With the birth of several hands-on social networks, the syndicates of human trafficking operate sophisticatedly by utilizing the new technology existing in developed and in developing countries meanwhile in the rural areas and villages in poor countries especially in Southeast Asia they work closely with the local people who act as the middlemen. Besides that, syndicates use new tactics by engaging young men to lure young girls into false love relationship and runaway due to infatuation. Then the men will lead the vulnerable girls to the syndicate or pimps and force them into prostitution by beating and raping them mercilessly. Women who are trapped in debt are forced into marrying local men so that the women can pay off her debt by serving as sex slaves. ${ }^{9}$

For that reason, there are three constituent elements involved in operating human trafficking. The first element is the act which determines what is done. The act involves recruitment, transportation, transfer, harbouring, or receipt of persons. The second element is the means of how it is done; which explains the threat or use of force, 
coercion, abduction, fraud, deception, abuse of power or vulnerability, or giving payments or benefits to a person in control of the victim. And the third element is the purpose on why it is done. The purpose implies exploitation by means of exploiting the prostitution of others, other means of sexual exploitation, forced labour, child labour, slavery or similar practices and the removal of organs without prior knowledge. ${ }^{10}$

Malaysia is not far behind from this crime, as the country has also become a target destination for perpetrators to traffic their victims and as a transit to other locations. Strategically located along the coastline in Southeast Asia and with its known porous border, Malaysia is not only attractive to traffickers but also an escapade for migrants, refugees, asylum seekers from poor socio-economic and unstable political neighbouring nations.

Trafficking in reality occurs from poorer to more prosperous countries and with the evolution of modern technology, communications and transportation, has enabled human trafficking syndicates and transnational organized crime groups to exploit vulnerable men, women and children for monetary profit. It is the fastest growing illicit business in the criminal activity globally and soon may overtake drugs and arms trading revenues. The logic behind such notion is because drugs once used its gone with onetime profit whereas sex sells and when a woman is forced to entertain countless men from day to night she brings in more cash to the table. ${ }^{11}$

To understand human trafficking, it is essential to relate the (structural factors) social, economic and political context to policy and governance issues (proximate factors). ${ }^{12}$ The interaction between structural factors and proximate factors explain why many individuals are vulnerable and how they are coerced and deceived into trafficking. ${ }^{13}$ Besides, the economic liberalization policies and technological innovation in telecommunication networks and transportation have increased the demand for cheap labour services as well as sexual services. ${ }^{14}$ Moreover, globalization has equally contributed to the expansion of human trafficking activities in every corner of the world with the increasingly porous state borders.

Both the structural and proximate factors assimilate the pull and push factors that motivate the activity of human trafficking on the local front, regional and internationally. State and non-state 
actors acknowledge these motivating factors, which induce human trafficking to operate at international scale. Transnational organized crimes impose security threats not only to humans but also to national as well as international security.

It is a global problem where it manifests in numerous regions in multilateral ways. ${ }^{15}$ The need for positive responses from numerous actors at international and regional levels with the involvement of various organizations, human rights bodies and associations and at societal level with the participation from people on the street and neighbourhood, it is possible to stop the human trafficking crime.

\section{INTERNATIONAL RESPONSES}

It has been a decade following the establishment of United Nations Convention against Transnational Organized Crime and the Trafficking in Persons Protocol and three years since the adoption of the Global Plan of Action to combat human trafficking ${ }^{16}$ though prior to that less efforts or rather none taken in addressing this crime. In December 2003, the UN enforced the Protocol to Prevent, Suppress and Punish Trafficking in Persons, Especially Women and Children supplementing the United Nations Convention against Transnational Organized Crime. Thus far 170 State Members of the UN have pledged their commitments in eradicating the problems of human trafficking in their respective countries in addition to ratifying the Protocol. ${ }^{17}$

Various international organizations and numerous human rights bodies have taken colossal initiative in the fight against human trafficking. This is a perilous crime in need of forceful states' and governments' responses in assisting and protecting the victims, implementing and practicing a rigorous criminal justice system in prosecuting the offenders with sound migration policy and firm regulation of the labour markets in tackling human trafficking in respective states. Between the years 2007 and 2010, from the 132 countries covered in the Trafficking in Persons Report in the year 2012 , only 16 per cent did not prosecute any convictions, nevertheless many more countries have reported more cases during that period. ${ }^{18}$

For states in conflict situations like war and extreme poverty are weak and fragile as a result are vulnerable to organized crimes such as human trafficking, people smuggling and drugs. ${ }^{19}$ The United Nations 
Office on Drugs and Crime (UNODC) Executive Director, Yury Fedotov acknowledged this problem and stated that organized crimes such as human trafficking alongside counterfeit medicines, terrorism and the illegal trade in wildlife, small arms and cultural artefacts are on the rise undermining sustainable development subsequently prevent access to education and employment, and impede the flow of foreign and domestic investments.

One of the main discussions to combat human trafficking at the UN General Assembly was to focus efforts on four pillars namely; preventing trafficking, prosecuting offenders, protecting victims and forming partnerships to fight trafficking. ${ }^{20}$ Top UN officials are stressing concerns and urging the State Members to fully implement key anti-human trafficking treaties as well as to collaborate closely to curb the crime. To achieve justice, a sound and strong foundation is crucial in the rule of law thus it is essential to strengthen the judicial system and aid the governments to earn the trust of their people. ${ }^{21}$

As a result, law enforcement and comprehensive policies ${ }^{22}$ with key stakeholders like the public, corporate sectors and the media in sharing the best practices with mutual legal aid, enhancing joint operations across borders, strengthening national security on human trafficking with regional and national approaches unquestionably vital. The fundamental framework designed to combat human trafficking and being used by government around the world is known as the ' $3 \mathrm{P}$ ' paradigm which stands for Prosecution, Protection and Prevention ${ }^{23}$ and the fourth 'P' was introduced for Partnership which serves as a bridge in achieving the success of the 3Ps structure to end the modernday slavery worldwide.

The fourth $\mathrm{P}$ in the framework was announced by the former Secretary of the United States of America, Hillary Rodham Clinton in 2009. This framework is not only a guideline but an essential tool for governments to utilize to the maximum and by partnering with neighbouring nations in curbing human trafficking and other odious organized crimes. Essentially Malaysia has partnered with several neighbouring states in the region not only to tackle the issue on human trafficking but also on migrant smuggling, asylum seekers and refugees who risk their lives by crossing violent seas in smalls boats and ending tragically. 


\section{REGIONAL RESPONSES}

At regional level, in Southeast Asia especially the Greater Mekong Subregion (GMS) is recognized as a prominent source and destination for human trafficking activities yet it is also considered to be a world leader in confronting and combating this crime. It is reported that some 500, 000 migrants are smuggled into Thailand every year and these migrants are unaware of the risks awaiting such as abuse, exploitation and becoming a prey of human traffickers. ${ }^{24}$ Due to these circumstances, some of the initiatives with numerous measures operate throughout the region with an aim to raise awareness and understanding not only on human trafficking issues but as well as on human or migrant smuggling.

The UNODC released a report which dedicates the happenings of human trafficking and migrant smuggling within the Greater Mekong Sub-region; From East and Southeast Asia to Europe and the United States; and From Southeast Asia to Australia and Canada in four chapters. Significant efforts as such boost protective factors; mitigate risks and vulnerabilities besides demonstrating best practices in bilateral and multilateral cooperation among states in the region.

Collaboration is essential among international bodies, individual nations, regions, NGOs as well as the private sectors for efforts in prevention, protection, detection and prosecution; with the implementation of domestic legislation; enforcing the law; investigation on various elements such as cross borders; raising awareness from grass roots to schools and public; and implementing international legal instruments. With all these international instruments and tools, which are designed and developed in addressing human trafficking, incidentally they may work for some countries and may not work for another. Hence, these international measures have to be adaptable and complement to be successful in other countries and regions as well. States who shy away from acknowledging the occurrence of human trafficking despite obvious evidence showing the very existence of the issue may face economy sanctions from international communities.

\section{THE MALAYSIAN GOVERNMENT'S RESPONSE}

According to the U.S TIP Report released on June 2013, Malaysia was placed in the Tier 2 Watch List for the fourth consecutive year with a 
reason that the government did not fully comply with the minimum standards for the elimination of human trafficking. ${ }^{25}$ Besides, it has failed to show overall increasing performance and efforts in addressing human trafficking compared to the year before. However, Malaysia was granted a waiver from downgraded to Tier 3 because the government has a written plan known as the National Action Plan for AntiTrafficking in Persons from 2010 to 2015. It is a five-year framework and by implementing this plan would show significant efforts by the government with its established anti-trafficking in person's secretariat council and by allocating sufficient resources in meeting the minimum standards to eliminate the human trafficking issues in the country.

In Malaysia, human trafficking issues fall under the purview of Ministry of Home Affairs which has established the Majlis AntiPemerdagangan Orang dan Anti-Penyeludupan Migran (MAPO) secretariat council in partnerships with numerous enforcement agencies and several local NGOs to curb this odious global crime. The government implemented the Anti-Trafficking in Persons (ATIP) Act in 2007 only after being listed on Tier 3 of the watch list nations indicating the lowest category by the U.S Department of State's Trafficking in Persons Report in 2006. ${ }^{26}$ The ATIP Act in particular recognizes the crimes of sexual exploitation, forced labour or services, slavery or practices similar to slavery, servitude, any illegal activity or the removal of human organs as purpose for exploitation.

Retrospectively, in the year 2009, Malaysia was blacklisted by the US Department of State for not complying with the Trafficking Victims Protection Acts (TVPA) and as a result was placed back on Tier 3 and among 16 other countries for bad record in handling this pertinent issue. ${ }^{27}$ This was a thwarting drop for the government since 2007 however, in 2008 the ranking improved by being on Tier 2 Watch List. Malaysia recurrence on the Tier 3 blacklist spot has sparked heated debate that it yet to fully tackle the concern of human trafficking issues in its country. Countries on Tier 3 list may be subjected to certain sanctions such as the withholding of non-humanitarian and non-traderelated foreign assistance, as well as U.S opposition to assistance from international financial institutions. This excludes humanitarian, trade-related and certain development-related assistance. However, sanctions would not be applied if the Tier 3 governments comply 
with minimum standards, or seen making significant efforts to comply before sanctions are decided.

Another bothering issue is that the Malaysian government was continuing to confine foreign victims in inadequate facilities and failed to provide these helpless victims with sufficient legal aid, translator to communicate with the victims who do not know any other languages besides their own mother tongue and psychological counselling. It was also highlighted that government certified victims are not allowed to reside outside the shelter facilities, which is deemed unsatisfactory. According to another report by the United Nations High Commissioner for Refugees (UNHCR) World Report 2011 on Malaysia, it had stated that the government does not fully comply with the minimum standards to eliminate trafficking, even so informed that the government was making significant efforts to curtail this crime. ${ }^{28}$

The efforts of the governments are assessed based on the enactment of laws forbidding ruthless forms of human trafficking as described by the TVPA and the stipulation of criminal penalties for trafficking offenses. In addition, the severity of the criminal penalties is taken into consideration or at least a maximum of four years imprisonment. Besides, the success of prosecution through the implementation of human trafficking laws to prevent any forms of human trafficking in the country. Apart from that, it is essential to have a proactive victim identification measures with systematic procedures in order to guide the enforcement of law and other government agencies front-line officers responding to the crime by processing the identification of human trafficking victims.

To combat human trafficking, effective partnership is important and any government for the matter is unable to tackle this large-scale problem all by itself. It is essential to partner with local NGOs and by funding the NGOs with ample resources, victims would be able to access primary healthcare, counseling and shelter facilities provided by the NGOs. Such measures would enable victims to recount their trafficking encounters to professional and trained social counselors and law enforcement in an environment of minimal pressure.

Countries are also evaluated by the extent of victim protection efforts which include access to services and shelters without detention and with legal alternatives to extradite to countries that they might 
face adversities. At the same time, the efforts of the government in providing legal aid and other assistance consistent with domestic law, proceedings which are not damaging to victim's rights, dignity or psychological well-being. It is also in ensuring the safe, humane, possible voluntary repatriation and reintegration of victims.

\section{Prosecution}

The Malaysian Ministry of Home Affairs has shown immense initiative in addressing and highlighting human trafficking throughout the country to create awareness among the civilians however in enforcing the law it is regarded as insufficient because so far only sex traffickers are convicted compare to those who have exploited men and women alike alongside underage children into forced and hard labour.

Prior to the introduction and implementation of the ATIP Act in 2007, Malaysia did not criminalize debt bondage or labour practices that promote involuntary domestic servitude and there was no judicial cases prosecuting traffickers. ${ }^{29}$ Due to political pressure which may impede relationship between U.S and Malaysia as well other nations and the Tier ranking of TVPA implies absence of significant efforts from the government of Malaysia in addressing human trafficking problems in the country.

In 2008, to assist the Council for Anti-Trafficking in Persons as provided under Section 6 [1] of the Anti-Trafficking in Persons Act 2007 [Act 670], The Secretariat of the Council for Anti-Trafficking in Persons (MAPO) was created and the act was passed in 2007 and enforced a year later. Due to extensive activities of human trafficking and smuggling of migrants, the act was amended in 2010 and is known as Anti-Trafficking in Persons and Anti-Smuggling of Migrants Act 2007.

And the council was renamed the Secretariat of the Council for Anti-Trafficking in Persons and Anti-Smuggling of Migrants with its mission to prevent and curb human trafficking crime and smuggling of migrants with systematic and consistent law enforcement. The MAPO council is supported by five enforcement agencies namely; Royal Malaysian Police, Malaysia Maritime Enforcement Agency, Malaysian Immigration Department, Royal Customs of Malaysia and Labour Department. For legal committee the Attorney General 
Chambers Office is at task; for victims' protection the Ministry of Women Development, Family and Society; and for media and publicity under the Ministry of Information, Communication and Cultural.

According to the newly amended law, the Anti-trafficking in Persons Act 2010 prohibits all myriad forms of human trafficking and the punishments are similar to other grave offences. If found guilty, minimum fine for profiting from trafficking human beings has been increased by ten-fold. The enacted new law ${ }^{30}$ penalties include the acquiring or maintaining the labour or services of an individual through oppression.

Even with the new amendments yet convictions are less imposed on perpetrators of forced labour. This is clearly seen when in 2011 the government of Malaysia prosecuted 17 sex trafficking offenders but did not indict any delinquents of forced labour whereas in 2010, about 14 convictions were prosecuted for both sex and labour trafficking. ${ }^{31}$ Judgment sentenced upon offenders is imprisonment from two to 30 years.

During the same year, based on police and immigration investigations, 97 suspected trafficking cases were reported of which 45 were labour trafficking cases. Hence, 16 cases were prosecuted with 13 engaged in sex trafficking and three for forced labour. ${ }^{32}$ However, the figure compare to previous year's conviction was a total of 231 and was ongoing but no matter how high the number of prosecution was initiated, the acquittals seem to be equally high. The U.S Department of States evaluates the governments' involvement in prosecuting alleged perpetrators. Malaysia has not shown favourable convictions on offenders caught and prosecuted on human trafficking cases.

For the first time the Labour Department as a council member of MAPO was given the authority to convict suspected human trafficking cases thus, in 2011 it filed three suspected labour trafficking perpetrators who were the owners of a media company GSS Agency forcing five Indian nationals to forced labour by distributing and selling newspapers. ${ }^{33}$ During the arrest, the five workers did not produce any relevant documents and as a result they were detained for violating immigration law and the employers who had taken away their documents were not charged at all resulting dissatisfaction among the members of the civil society. Not only that, there were no reliable 
witnesses prepared to prosecute the employers effectively when the case was produced with elements of labour trafficking. Due to the pressure from the public and NGOs, the Labour Department was forced to investigate the case but till now it is ongoing.

This clearly shows that there is an ignorant attitude in convicting the employers possibly due to their position in the public and as a member of a media company. It implies the lack of collaboration between NGOs and prosecutors to bring those who violate the ATIP law to justice and it is a hurdle for a nation to combat the crime of human trafficking.

Meanwhile, on numerous occasions, government officials were detained for their direct involvement in human trafficking and so far only one offender has been prosecuted in December 2008 under the 2007 anti-trafficking law. In 2010, it was reported that seven immigration department officials who were the employees of the Immigration Department under the jurisdiction of the Ministry of Home Affairs Malaysia were involved in human trafficking activities in the country. ${ }^{34}$ These accused together with two Indonesians were detained under the Internal Security Act (ISA) for indefinite detention without trial and later on they were pardoned for repenting.

By applying the ISA to offenders of human trafficking has weakened the prosecution cases and it does not only defeat the purpose of implementing the ATIP law but raises concern over the government's motive and intention in not convicting the perpetrators in an open court. It denies human rights to an open, fair and just trial for the victims who suffered in the hands of the traffickers. However, according to Malaysian Human Rights Commission (SUHAKAM), ISA should not be used on human trafficking offenders, as it is ineffective in elimination the root cause of the issue. Besides, the use of ISA reflects false impression on the actual trafficking activities in the country and once they are released from detention without trial, they could continue with the offense.

Based on the statistic provided by the MAPO council of the Home Ministry, the number of cases of trafficking in persons from the year 2008 to 2012 is a total of 591 and total number of arrest made is 797. ${ }^{35}$ It was also reported that there were two foreigners suspected of human trafficking crime and were detained without trial in Kamunting 
Detention Centre. ${ }^{36}$ One of them is a Sri Lankan detained since 2009 and another suspect is an Iraqi locked up since 2011. Both detainees' arrests have been extended to $2013 .{ }^{37}$ Both detainees were on hunger strike as they disagreed with their detention without trial. This action had inflicted bad image on the Malaysian government besides certain groups have been arrested, detained and deported as the system has ineffective and inconsistent screening on alleged human trafficking offenders.

Meanwhile in 2008 and 2011, two individuals were convicted under the ATIP Act for labour trafficking and each were imposed an eight-year imprisonment; however when eight immigration officials were detained for the same offense they were detained for 10 months without trial and later on were released as they all claimed regret and have repented over their mistakes. ${ }^{38}$ However, these eight immigration officers were sacked after their release not only from their department but from any other government body or agency. Though some human rights groups and NGOs wanted them to be charged and prosecuted.

In another case, eleven Uighurs from China were suspected of their involvement in human trafficking thus they were deported to China without being charged. ${ }^{39}$ Because the state did not show a consistent in conviction and prosecution, whereas reflected prejudices for being inconsistent in the penalties for different offenders from 2008 to 2011, the Malaysian Human Rights Commission (SUHAKAM) questioned the government on its criteria and rationale used on prosecuting and punishing human trafficking perpetrators. Despite the protest by UNHCR and civil society to stop the deportation as the Uighurs would face persecution in China, the Malaysian government deported them immediately fulfilling the request of the Chinese government. And still there are 16 people arrested under the 'ISA 1960' for human trafficking crime ${ }^{40}$ and uncertain of their trials.

Though with new amended legislation, the anti-trafficking law failed to include sufficient provision for the security of victims and the freedom for these victims to reside outside the government shelters and also those in closed shelter facilities resembling detention centres. The implemented new amendments conflate trafficking victims with smuggled migrant workers whilst reduce protection for both groups thus disable the victims to cooperate in identifying the perpetrators. 


\section{Prevention}

The prevention efforts are a key element of the global movement in monitoring and curbing human trafficking. These efforts are not only for the public but also for the many migrants out there and especially for those in vulnerable situations. In some working sectors where human trafficking is prominent especially at construction sites, plantations, fish farms and fishing villages; prevention measures are essential in order to protect labours that may fall into the category of trafficking victims. Therefore, implementing law enforcement in particular key sectors is indeed crucial. Prudent labour recruitment programs should be in place not only for protection but to prevent exploitation from occurring at the hands of immoral perpetrators.

The Malaysian government and its agencies have been proactive and in open discussion as well as bridging gap with selective NGOs and states in implementing the National Action Plan. Some local NGOs who have been advocating the fight against human trafficking before the implementation of ATIP and the establishment of the MAPO Council were not included in the government's policy discussions and the reason supplied was that certain NGOs are very criticizing instead of advocating. This action plan is a strategic direction for the next five years and the primary objective is to combat human trafficking and to enrich support programmes as well as to ensure the effective implementation of the strategic goals. ${ }^{41}$

The National Action Plan against Trafficking in Persons is the first official document outlining the Malaysian government's commitment in tackling human trafficking activities in the country. This National Action Plan serves as a guideline in order to overcome the problem of trafficking in persons as well as complement the existing ATIP Act 2007. Whereas the MAPO council has its roleplay and function to support the ATIP Act 2010 with a clear vision to be recognized globally as a nation free from human trafficking and migrants smuggling.

The government realized the depth of this crime when it gained global attention as a serious cross-border crime similar to trafficking of weapons and drugs. Following the huge profits earned in billions as a result of illegal activity, a large number of crime victims, especially women and children were snatched off their dignity, freedom and 
human rights. An increase in global migration estimated a total of 240 million people scream for attention as a large portion from this figure unfortunately fall prey to unscrupulous individuals and syndicates of human trafficking.

Therefore, the Malaysian Government recognizes the importance of creating ATIP Act 2007 [Act 670] and the National Action Plan as an instrument for addressing crime, especially on the areas of prevention, rehabilitation and protection of trafficking victims, including prosecution.

Key source of reference in establishing the Anti-Trafficking in Persons Act 2007 is based on international instruments namely, the Protocol to Prevent, Suppress and Punish Trafficking in Persons, especially Women and Children (TIP Protocol) and Protocol Against the Smuggling of Migrants by Land, Sea and Air. Both protocols are tools that support the United Nations Convention against Transnational Organized Crime (UNTOC) and Malaysia has signed and ratified the convention and joint hands with TIP Protocol in fighting the human trafficking crime.

Apart from this Act, there are other domestic legislations which are in place as a support such as the Immigration Act 1959/63 [Act 155], the Malaysian Maritime Enforcement Agency Act 2004 [Act 633], the Customs Act, 1967 [Act 235], the Evidence Act 1950 [Act 56], Court of Judiciary Act 1964 [Act 91], Child Act 2001 [Act 611], the Penal Code [Act 574], Restricted Residence Act 1933 [Act 377] and the Emergency Ordinance 5/69.

In addition, Malaysia's initiative to combat crime of trafficking in persons is also in line with the ASEAN Declaration against Trafficking in Persons Particularly Women and Children, United Nations Declaration on Human Rights [UDHR] 1949, Convention of the Elimination of All Forms Discrimination Against Women [CEDAW] 1979 and Convention on the Rights of the Child [CRC] 1989.

The National Action Plan has been developed to clearly identify the direction and focus in achieving national goals for preventing and combating trafficking in persons in Malaysia. Its objective is to ensure the strategic direction is attained, to determine strategic goals that will guide and drive national efforts to combat human trafficking and to 
establish program areas in supporting and ascertaining the effective implementation of the strategic goals.

With a clear mission and innovative vision, the MAPO council has set up mini MAPO in all the states in Malaysia in order to coordinate human trafficking cases. ${ }^{42}$ These mini MAPOs are headed by the respective state's chief police with members including officers from enforcement agencies like the police, immigration, customs, maritime, women development department, welfare department and representative from NGOs. To enhance the line-up in the states, court directors, state chief prosecuting unit and shelter home operators are also included as members of mini MAPO.

At national as well as state levels, the affiliate members of MAPO have organized events to raise awareness campaigns via print media, television programmes and radio as well as social network. In November 2011, the Human Resource Ministry's official gave a talk on a prime time news program on the new provisions of an agreement signed with Indonesia and also on exercising the ATIP law by criminally prosecuting exploitative employers besides encouraging the public to be alert on abuses and to report them. In 2012 the members of the council appeared on Bella programme on NTV7 and then on the Radio Era subsequently in 2013 on BFM Radio. Local NGOs like Coalition to Abolish Modern-day Slavery in Asia (CAMSA), National Council for Women's Organization (NCWO) an agency under the purview of Ministry of Women, Family and Community Development are members of the MAPO secretariat council and they utilize the social network such as Facebook to highlight their activities and events on human trafficking. These NGOs with the rest of the affiliate and non-affiliate members of the MAPO collaborate in organizing programmes to create awareness on human trafficking by encouraging corporate organizations participation in their campaigns and events around Malaysia. Besides there are numerous brochures and posters on human trafficking and migrant smugglings found in higher learning institutions and in public vicinities to educate the society.

To prevent mistreatment from the employers and for the workers to have a better understanding of their responsibilities, both employers and workers are urged to attend a seminar at the agency. Some employers fail to adhere to the signed agreement by confiscating the 
workers' passport and as a result the Memorandum of Understanding (MOU) signed between countries is unable to protect the domestic workers. The employers were not charged or imposed a fine for taking away their employees' passports or important travelling document though it is strictly prohibited. And some workers are confined to their workplace and do not have the freedom to go anywhere or do anything. Some were not fed sufficiently nor given a rest day at all and their wages were held back. By withholding the wages of domestic workers and forcing the workers to work without proper food and rest are actions of human trafficking. By exploiting them into forced working conditions and into an act of slavery constitutes trafficking in persons. ${ }^{43}$

While government agencies continue with their preventive measures by conducting training and workshop for their incumbent officials in combating human trafficking in Malaysia still there is a lack of knowledge and understanding the crisis of human trafficking by the front-line officials like the police, marine, immigration, labour officials which continue to be a challenge in educating them. This may hinder process of identifying and investigating trafficking cases and in assisting the victims.

\section{Protection}

Protection is another pertinent key of 3Ps framework of the TIP Protocol and it is a victim-centric approach developed by the US and international community in order to pursue effective efforts in combating human trafficking. The elements in the protection efforts comprises of $3 \mathrm{Rs}$, namely rescue, rehabilitation and reintegration.

The Employment Act $1955^{44}$ explains that when a person's wages is held back, forced to do things that not supposed to do, and then inflict physical and emotional abuse besides forced to starve; this is categorized as an act of human trafficking. Because human trafficking is not only about transporting a person from a state to another place without the consent, however the definition goes beyond the depth of the action inflicted upon and forced to do. There is a lack of awareness on the fact that someone could be a victim of human trafficking and not an offender. 
To protect the victims of human trafficking, the government has established five shelter homes under the purview of the Ministry of Women, Family and Community Development with three facilities established for women and child victims of trafficking and one for men. These victims are protected under Interim Protection Order (IPO) and Protection Order (PO). The MAPO council presents a statistic from the year 2008 until 2012 indicating a total of 3363 victims under IPO and a total of 1235 victims under PO. ${ }^{45}$ From this figure, 428 victims are of sex exploitation, 25 victims of human trafficking and migrant smuggling, 10 babies and 33 abuse cases. ${ }^{46}$ However, the reason for placing victims of different cases in the same shelter for human trafficking is unknown. This might be due to lack of facilities and also for short stay.

The IPOs are entitled for suspected victims of human trafficking for 14 days and once confirmed then they are placed under PO. Victims of local citizen are sheltered for not more than two years whereas foreigners for not more than three years. Though the government has made sufficient progress in protecting the human trafficking victims, yet it remained inadequate and negatively affected the victims. ${ }^{47}$

There is a lack of legal aid and counselling support rendered to the victims by the government agencies, its NGOs or even by the local NGOs. Instead the government has used large funding in building the shelters with high security alarm to prevent the victims for running away. This method contradicts with the 3P protocol where a government is required to look into the needs of a victim and the priority to protect them is paramount and to restore their dignity is crucial and to provide an opportunity for a safe and productive life.

The government prefers to confine the victims of human trafficking in its own shelter facilities even though some NGOs have the resources to serve and provide a safe and comfortable environment in undisclosed locations. Some foreign embassies shelter their victims rather than sending them to Malaysian shelters also to expedite the process of repatriation. It is also to protect the victims from staying longer in the country for criminal proceedings. Not the same scenario for some unidentified victims whose passports and relevant documents confiscated by their employers and as a result they were processed as illegal migrants and held in prisons or immigration detention camp before deportation. 
For the Malaysian government to effectively implement the 'Rest', it should allow the identified human trafficking victims to stay in the country to work without having the fear of detention or deportation for lack of legal status or crimes that they were forced to commit by their traffickers. Accordingly, in January 2012 the Malaysian government granted some of the victims to work temporarily in the country following the expiration of their PO. Two months later, the government granted three-year work and residency permits to 32 victims of labour trafficking whose lives were believed to be in danger back at their home country. Prior to the three-year permit, these victims had already stayed for more than one and a half years in the government shelter. However, this offer is only for victims who had entered Malaysia legally and lives are in danger if they were to return home.

An effective partnership is pertinent between law enforcement and service providers in caring for the victims of human trafficking. Detained victims were asked to recount their trafficking experience on numerous counts to different officials and during the trial proceedings victims were not separated from the traffickers or recruitment agents resulting in threats and pressure stressed on the victims and their families for cooperating with the police and prosecutors.

Rehabilitation efforts are to afford emergency assistance and services, effective placement in stable, long-term situations, and access to educational, vocational and economic opportunities for these survivors of modern-day slavery. Besides, reintegration efforts are voluntary repatriation for trafficking victims and assistance in their home communities which would be a motivation to build their lives back.

At the shelter facilities, there are challenges for the service providers who oversee day to day events. With limited staff, space and infrastructure for the victims, the caretaker find it a huge challenge to keep things moving. As some victims are confined to their rooms and lack of manpower disable them to offer sufficient services. The shelter homes enable to accommodate 60 to 80 victims and at times when there is an urgent need, the enforcement officers have to place the victims in the shelters regardless of limited capacity. 
It is important to protect the victims, suspected or actual victims during identification, interview and referring trafficking victims however, according to the country report from the US State Department, but there was no evidence of any existence of formal procedures to follow for the proactive identification of victims among vulnerable groups with whom the authorities came in contact.

\section{CONCLUSION}

The Malaysian government is accomplishing significantly in combating human trafficking however there are rooms for improvement. The government should consider working with other NGOs besides its MAPO affiliates in preventing this crime and in protecting the victims of human trafficking. Malaysia has to maintain its placing on the TVPA, if it falls to Tier 3, the U.S government would impose economic sanction. Hence, one of the current initiatives engaged by the government is by allowing the victims to work outside the shelter premises. $^{48}$

While the authorities continue to train government officials to combat human trafficking in the country, they should consider incorporating international organizations and donors to overcome the lack of knowledge on this issue. Many front-line government officials especially the enforcement agencies need to be educated on identifying and assisting the victims and in doing proper investigation on trafficking cases. Such measures would surely aid in smooth operation in combating human trafficking in Malaysia.

\section{NOTES}

1 Louise Shelley, John Picarelli and Chris Corpora, "Global Crime Inc.," in Maryann Cusimano Love (ed.), Beyond Sovereignty: Issues for a Global Agenda, Boston: Thomson Wadsworth, 2003, pp. 143-166.

2 International Labour Organization (ILO), "Action against trafficking in human beings," UNODC Border Liaison Offices in Southeast Asia 19992009, Ten Years of Fighting Transnational Organised Crime, Vienna: United Nations Office on Drugs and Crime (UNODC), 2008.

3 Office of the Under Secretary for Civilian Security, Democracy and Human Rights, Trafficking in Persons Report, Washington, DC: Department of State, June 2013. 
4 Kofi Annan, "Chapter 3," Millennium Report, New York: United Nations, 2000, pp. 43-44.

5 In Article 3 Paragraph (a) of the Protocol to Prevent, Suppress and Punish Trafficking in Persons that was signed in Palermo City, Italy, in 2000, the UN describes exploitation to include, at a minimum, the exploitation of the prostitution of others or other forms of sexual exploitation, forced labour or services, slavery or practices similar to slavery, servitude or removal of organs. See United Nations Convention against Transnational Organized Crime and the Protocols Thereto, Vienna: UNODC, 2004.

6 Kevin Bales, Disposable People: New Slavery in the Global Economy, Berkley: University of California Press, 2004.

7 Ibid. Janie Chuang, "Beyond a Snapshot: Preventing Human Trafficking in the Global Economy," Indiana Journal of Global Legal Studies, Vol. 13, No. 1, 2006, pp. 137-163.

8 John Winterdyk, Benjamin Perrin, and Philip Reichel (eds.), Human Trafficking - Exploring the International Nature, Concerns, and Complexities, New York: CRC Press, 2012.

9 "Human Trafficking Syndicates Using New Tactics," The Borneo Post, 24 March 2012.

10 UNODC, "What Is Human Trafficking," > http://www.unodc.org/unode/ en/human-trafficking/what-is-human-trafficking.html>

11 Ammu Kannampilly, "No Justice for Nepal's Slave Girls," The Star, 9 February 2014; and Lim Chia Ying, "Despicable Act Documented," The Star, 10 April 2012.

12 Sally Cameron and Edward Newman (eds.), Trafficking in Humans: Social, Cultural and Political Dimensions, New York: United Nations University (UNU), 2008.

13 Ibid.

14 H. Richard Friman, Human Trafficking, Human Security, and the Balkans, Pittsburgh, PA: University of Pittsburgh Press, 2007.

15 The White House, "Transnational Organized Crime: A Growing Threat to National and International Security," Washington, DC: The White House, $<$ http://www.whitehouse.gov/administration/eop/nsc/transnational-crime/ threat>

16 UNODC, "General Assembly Reviews Efforts to Combat Human Trafficking," 13 May 2013, <http://www.unodc.org/unodc/en/frontpage/2013/ May/general-assembly-reviews-efforts-to-combat-human-trafficking.html> 17 Ibid.

18 Global Report on Trafficking in Persons, Vienna: UNODC, December 2012. 
19 "Fighting international crime is key to sustainable development, UN official says," UN News Centre, 22 April 2013, $<\mathrm{http}$ ://www.un.org/apps/news/story.asp?NewsID $=44717 \& \mathrm{Cr}=$ unodc $\& \mathrm{Cr} 1$ $=\& \mathrm{Kw} 1=$ human + trafficking $\& \mathrm{Kw} 2=\& \mathrm{Kw} 3=\# . \mathrm{UZmkuKKw} 1 \mathrm{Jm}>$

20 "UN Member States appraise Global Action Plan to combat human trafficking," UN News Centre, 13 May 2013, $<$ http://www.un.org/apps/news/story.asp?NewsID $=44885 \&$ Cr=trafficking $\& \mathrm{Cr} 1=\#>$

21 Ibid. This was also mentioned by Ban Ki-moon, the current Secretary General of United Nations at the UN General Assembly on 13 May 2013. 22 UNODC, "Law Enforcement and Comprehensive Policies Key to Fight Asia Migrant Smuggling," 31 May 2013, <http://www.unodc.org/unodc/en/ frontpage/2013/May/law-enforcement-and-consistent-and-comprehensivepolicies-key-to-fight-asia-migrant-smuggling.html>; and Transnational Organized Crime in East Asia and the Pacific - A Threat Assessment, Vienna: UNODC, 2013. The latter work contains extensive information on migrant smuggling mainly from Myanmar, Cambodia and Lao PDR into Thailand while China and Vietnam are source countries for migrants to be smuggled to the US and EU.

23 The United States follows this approach which was reflected in the Palermo Protocol (United Nations Protocol to Prevent, Suppress and Punish Trafficking in Persons, Especially Women and Children) and in the United States' Trafficking Victims Protection Act (TVPA). The U.S. State Department's Office to Monitor and Combat Trafficking in Persons utilizes diplomatic, economic, political, legal and cultural tools to exhibit the '3P' paradigm globally.

24 Ibid.

25 Office of the Under Secretary for Civilian Security, Democracy and Human Rights, Trafficking in Persons Report.

26 Daniel Lo, Investigations: What Are the Key Elements in a Trafficking in Persons Case?, Kuala Lumpur: The Law Review, 2010. See the Guide to Tiers section in the Office of the Under Secretary for Civilian Security, Democracy and Human Rights, Trafficking in Persons Report. The guide explains that Tier 3 - Countries whose governments do not fully comply with the minimum standards and are not making significant efforts to do so; See the Country Narratives section in Office of the Under Secretary for Civilian Security, Democracy and Human Rights, Trafficking in Persons Report. 27 "Malaysia Listed as Worst Offenders of Human Trafficking," The Sun, 13 June 2007. 
28 "United Nation High Commissioner for Refugees Report," $<$ www.unhcr.org/refworld/country $>$

29 Pooja Terasha Stanslas, "The Human Trafficking Problem in US-Malaysia Relations," Asia Pacific Bulletin, No. 88, 15 December 2010.

30 The government of Malaysia enacted amendments to the law which gave a broad definition on trafficking and revised the penalties to become more severe. It was amended in November 2010.

31 Data obtained from Malaysian Attorney of General's Office and is used here with permission. See also, the Country Narratives section in Office of the Under Secretary for Civilian Security, Democracy and Human Rights, Trafficking in Persons Report.

32 Ibid. Irene Fernandez, "Human Trafficking: Raise Transparency to Ensure Effective Prosecution," Malaysian Chronicle, 28 June 2012.

33 Irene Fernandez, "Government Must End Slavery, Forced Labour in Malaysia," Malaysiakini, 18 December 2011, <http://www.malaysiakini. com/letters/184447>

34 "Malaysia Accuses Immigration Officials of Human Trafficking," Inquirer Global Nation, 13 October $2010<$ http://globalnation.inquirer.net/news/ breakingnews/view/20101013-297563/Malaysia-accuses-immigrationofficials-of-human-trafficking >; "Nine Arrested under Isa," The Sun, 13 October 2010; Fernandez, "Human Trafficking"; "Five Immigration Officers Nabbed for Human Trafficking," The Sun, 20 July 2009; and "Indian National Charged with Human Trafficking," The Sun, 29 December 2011.

35 Malaysian Anti-Trafficking in Persons Unit (MAPO), "Statistic Cases for Trafficking in Persons from 28 February 2008 to 30 November 2012," $<$ http://www.moha.gov.my/index.php/en/sekretariat-statistik>

36 Farrah Naz Karim and Alang Bendahara, "Making Millions from Behind Bars," New Straits Times, 10 September 2012; Farrah Naz Karim and Alang Bendahara, and "Undeclared Millionaires," New Straits Times, 11 September 2012. In both these articles, the journalists descriptively have written on how the perpetrators were still making money and running their business from detention centres in Kamunting, Perak, Malaysia.

37 Human Rights Watch, "World Report 2011 - Malaysia," 24 January 2011, <http://www.hrw.org/world-report-2011/malaysia>; Human Rights Watch, "World Report 2012 - Malaysia," January 2012, <http://www.hrw. org/world-report-2012/world-report-2012-malaysia>

38 Azril Annuar, "Eight Officers Were Sacked: Immigration DG," The Sun, 9 August 2011. 
39 SUHAKAM filed this in its Annual Report 2011 in Parliament on 26 March 2012; "Annual Report 2012," in The State of the World's Human Rights, London: Amnesty International, 2012.

40 Bar Council of Malaysia, "Submission of Bar Council Malaysia for the Universal Periodic Review of Malaysia 2013," 11 March 2013, $<$ http://wao.org.my/file/file/Bar\%20Council\%20Malaysia\%20UPR\%20 2013\%20Submission.pdf>

${ }^{41}$ Majlis Antipemerdagangan Orang, Pelan Tindakan Kebangsaan Anti Pemerdagangan Orang (2010-2015), Putrajaya: Ministry of Home Affairs, Malaysia, 2010.

42 Karen Arukesamy, "Mini MAPO in all States," The Sun, 11 August 2011. 43 UNODC, "What Is Human Trafficking."

44 According to the Malaysian Employment Act 1955 which enlists types of forced labour, an employer can be prosecuted for bonded labour, cheating during recruitment, fails to adhere to the terms and conditions, fails to pay or delays in paying less than 70 percent of their wages, fails to give a rest day, annual leave and sick leave. However, if violence occurs, the case is filed under criminal charges and is under the jurisdiction of the police. For runaway cases, it is under the purview of the Malaysian Immigration Department. So far, the Malaysian Labour Department has filed two cases in which they lost in both cases. The seminar entitled "Awareness Campaign on Human Trafficking and Migrant Smuggling," organized by Institute of Malaysian and International Studies (IKMAS), National University Malaysia (UKM) with MAPO council on 20 September 2012, in University Malaya, Kuala Lumour.

45 See MAPO, "Statistic Cases for Trafficking in Persons from 28 February 2008 to 30 November 2012."

46 This figure was gathered during the seminar from the Shelter Facility Service officer for Human Trafficking and Migrant Smuggling, 20 September 2012.

47 Office of the Under Secretary for Civilian Security, Democracy and Human Rights, Trafficking in Persons Report.

48 Ministry of Home Affairs, "Media Statement: Permission to Work for Labour Trafficking," 5 March 2014, <http://www.moha.gov.my/index. php/en/kenyataan-media-akhbar/1470-chairman-of-the-council-for-antitrafficking-in-persons-and-anti-smuggling-of-migrant-mapo-cum-secretarygeneral-of-the-ministry-of-home-affairs-datuk-seri-mohamad-khalid-shariffpermission-to-work-for-labour-trafficking-victims> 